\title{
Nutrition and lactation
}

\author{
R. G. WHITEHEAD \\ Ph.D., M.A., F.I.Biol. \\ Medical Research Council Dunn Nutrition Unit, Milton Road, Cambridge CB1 4XJ
}

\begin{abstract}
Summary
Recommended dietary allowances for women during pregnancy are discussed in the light of actual intakes both in the developing and industrialized countries. The difference between total energy intakes in the industrialized countries (around $2900 \mathrm{kcal}$ ) and in the developing countries (around $1600 \mathrm{kcal}$ ) is emphasized. Data are provided from The Gambia which demonstrate the effect of seasonal changes in maternal dietary intake on the quantity of breast milk produced and on its quality. The relationship between breastmilk supply and infant growth is also demonstrated.
\end{abstract}

\section{Introduction}

Professor Hytten (Hytten, 1979) has discussed the relationship between maternal nutrition and the outcome of pregnancy. What he has said could be equally relevant to successful long-term lactation, because capacity for lactation may well be influenced by what the mother's diet has been during her pregnancy, as well as whilst she has been nursing. Nutritionists, like paediatricians and gynaecologists, have come to recognize that healthy fetal and early infant life are closely linked to the well-being of the mother.

In this paper, however, the author will be concentrating primarily on maternal dietary intake during lactation. Firstly he will review the extra nutrient allowances that various expert committees have thought it advisable to recommend to cover the increased demands of lactations. Then, he will consider practical situations, both in the industrialized and developing countries, where mothers may not be receiving these recommended levels, to see what effect variations in dietary intake actually have on the quality and quantity of milk produced. Human lactation is such a natural process that it has not really been subjected to the rigorous scientific study it deserves. It is hoped that the author of a book on the subject, recently published under the title The Tender Gift (Raphael, 1976), will not object if it is here stated that her title illustrates a common oversimplified approach which, for the uncritical, can lead to attitudes harmful to the young infant. Breast milk is not a gift: the nutrients contained in milk do not materialize out of thin air. Either directly or indirectly they must come from the mother's diet.

Most expert committees have assumed that the needs of an infant will be satisfied by a milk output of $850 \mathrm{ml} /$ day. In communities where lactation is a normal event lactation lasts for at least one year and Table 1 shows the average amounts of various

TABLE 1. Energy and nutrient content in one year's supply of breast milk*

\begin{tabular}{lcll}
\hline Energy & $217,175 \mathrm{kcal}$ & Iron & $240 \mathrm{mg}$ \\
Protein & $3.3 \mathrm{~kg}$ & Vitamin A & $186 \mathrm{mg}$ \\
Fat & $13 \mathrm{~kg}$ & Vitamin C & $12 \mathrm{~g}$ \\
Carbohydrate & $23 \mathrm{~kg}$ & Riboflavin & $95 \mathrm{mg}$ \\
Calcium & $1.1 \mathrm{~kg}$ & Folic acid & $16 \mathrm{mg}$ \\
\hline
\end{tabular}

* These data are based on the assumption that the milk yield is $850 \mathrm{ml} /$ day and the milk has the composition described in DHSS, 1977.

nutrients which would be contained in a typical year's supply - based on the latest analyses which have been carried out in milk from British mothers (Department of Health and Social Security (DHSS), 1977). Using energy as a baseline and assuming an efficiency of dietary energy conversion of $80 \%$, the average British mother would need to consume $165 \mathrm{~kg}$ extra food to produce this amount of milk; in a typical developing country (The Gambia) it would be $247 \mathrm{~kg}$ because of the low energy content of the diet. In communities where food is in short supply it is not surprising that many women do not receive anything like so much extra food.

\section{Recommended dietary allowances Protein and energy}

Perhaps the most complete set of dietary recommendations for lactation are those in the American 
National Research Council Recommended Dietary Allowances (National Research Council (NRC), 1974) and these are summarized in Table 2.

TABLE 2. Extra daily nutrient allowances for lactation (NRC, 1964)

\begin{tabular}{lccc}
\hline Nutrient & Non-lactating & Lactating & Increase \\
\hline Energy (kcal) & 2100 & 2600 & 500 \\
Protein $(\mathrm{g})$ & 46 & 66 & 20 \\
Retinol $(\mu \mathrm{g})$ & 800 & 1200 & 400 \\
Vitamin D $(\mu \mathrm{g})$ & 10 & 10 & 0 \\
Vitamin E (mg) & 12 & 15 & 3 \\
Vitamin C (mg) & 45 & 80 & 35 \\
Riboflavine (mg) & $1 \cdot 5$ & $2 \cdot 0$ & $0 \cdot 5$ \\
Nicotinic acid (mg) & 14 & 18 & 4 \\
Vitamin B $(\mathrm{mg})$ & $2 \cdot 0$ & $2 \cdot 5$ & $0 \cdot 5$ \\
Folate $(\mu \mathrm{g})$ & 400 & 600 & 200 \\
Thiamine $(\mathrm{mg})$ & $1 \cdot 0$ & $1 \cdot 3$ & $0 \cdot 3$ \\
Calcium $(\mathrm{mg})$ & 800 & 1200 & 400 \\
Iron $(\mathrm{mg})$ & 18 & 18 & 0 \\
Zinc $(\mathrm{mg})$ & 15 & 25 & 10 \\
\hline
\end{tabular}

It is very difficult to define exactly how much extra dietary energy is needed and any recommendation can only be a rough guide. It is important to pay adequate attention to individual circumstances. One complicating factor is the amount of fat which has been laid down during pregnancy. If this is little, then more dietary energy during lactation is needed, and vice versa. The amount of dietary energy required also depends upon the work a woman does. In some societies pregnancy and nursing are not allowed to make any difference and women continue with hard manual work. In other countries women are protected at this time and assume a more or less sedentary existence, and thus do not need so much extra energy. The extra protein allowance of $20 \mathrm{~g} /$ day is based on the assumption that the milk contains $1.2 \mathrm{~g}$ protein $/ 100 \mathrm{ml}$ and that dietary nitrogen is utilized with normal efficiency. There is also a generous allowance for individual variation.

\section{Vitamins}

Breast milk contains about $50 \mu \mathrm{g}$ retinol $/ 100 \mathrm{ml}$ and, on the assumption that the mother will secrete $850 \mathrm{ml}$, an extra dietary allowance of around $400 \mu \mathrm{g} /$ day is made by most authorities for lactation. The reader will notice that no extra allowance has been made to cover vitamin $D$. This does not mean, of course, that breast milk contains no vitamin D it does, in the water-soluble sulphate form - but it is always difficult to define allowances for this vitamin because so much is synthetized via sunlight and the skin. The $10 \mu \mathrm{g}$ is very much a token safety allowance for the non-lactating as well as the lactating mother. The extra vitamin $\mathrm{E}$ allowance was fixed on the basis of the concentration of $\alpha$-tocopherol in human breast milk.
Considerable extra allowances have also been made by the Americans for vitamin $\mathrm{C}$ during lactation, to allow for the vitamin $\mathrm{C}$ content of breast milk. Most lactating women also secrete $\mathbf{0 . 3}$ $0.5 \mathrm{mg}$ riboflavin in their breast milk each day and the extra $0.5 \mathrm{mg}$ allowance is to cover this amount.

Allowances for nicotinic acid are somewhat arbitrary and emphasize another of the difficulties in establishing needs for lactations. There is the possibility, with a number of nutrients, that metabolic efficiency, in this case the conversion of tryptophan to nicotinic acid, may be greater when needs are greater. With nicotinic acid this increased efficiency is by no means proved and most expert committees have assumed that extra vitamin allowances should be increased proportionately with energy at these times, and that is the reason for the extra $4 \mathrm{mg}$. Likewise with vitamin $B_{6}$, there is little or no decisive information on the needs of either pregnant or lactating mothers and the extra $0.5 \mathrm{mg} /$ day made by the National Research Council is largely arbitrary.

Breast milk contains about $50 \mu \mathrm{g}$ of folate per litre, and, assuming a $25 \%$ efficiency of digestion, absorption and conversion to milk folate, an extra $200 \mu \mathrm{g} /$ day is usually recommended for lactating women. The thiamine increment is to cover the extra dietary energy recommended for lactation. Thiamine is essential for the metabolism of carbohydrates. Breast milk does not contain large amounts of vitamin $B_{12}$ and the $3 \mu \mathrm{g} /$ day allowed for nonpregnant women would probably sustain the mothers through lactation as well; but nevertheless an extra one $\mu \mathrm{g}$ has been allowed by the Americans, more as a token than anything else, for lactating women.

\section{Minerals}

Breast milk contains considerable amounts of calcium and the breast milk secreted each day represents a net loss to the mother of some 250 $300 \mathrm{mg}$ calcium. For this reason the National Research Council have allowed-like FAO/WHO (1962) - an extra $400 \mathrm{mg}$. It must be remembered, however, that we are by no means sure of the calcium requirements of non-pregnant women. It appears that people who habitually live on low calcium intakes may utilize dietary calcium much more efficiently than, say, the average woman would do in the U.S.A.

Defining iron requirements for women on a public health basis is always difficult. The reader will note that the NRC (1974) have made no extra allowance to cover lactation. This is for 3 reasons: breast milk does not contain very much iron, amenorrhoea is usually a feature during lactation, and finally American allowances for non-pregnant women are already high - many would say impracticably high; 
certainly they are more than the corresponding DHSS (1969) recommendations. It would be the opinion of many nutritionists that the most rational procedure is for the doctor to assess a mother's iron requirements clinically on an individual basis and to provide iron in medicinal form to those who prove to have particularly high needs.

Considerably enhanced allowances are also recommended for zinc. Zinc is important for infant growth. As with calcium, however, it seems likely that maternal need and the efficiency of utilization will depend greatly on the dietary level to which the individual has become accustomed. This is particularly important when one considers the developing countries; an uncritical extrapolation from U.S.A. recommendations may not always be fully justified.

\section{The practical situation}

These, then, are the theoretical extra requirements for lactation. In practice, many women come nowhere near receiving extra allowances of this magnitude. What effect does this have on the quantity and quality of milk produced by the mother and on the growth and development of her offspring?

This is a question of importance not just to the developing countries, but for the Western world as well. In the industrialized countries too little attention has been paid to whether or not the understandable desire of a woman to regain her figure quickly might mean she eats too little, thus minimizing her ability to produce sufficient milk to meet the increasing demands of her growing infant. In a recent survey commissioned by DHSS (Martin, 1978), the main reason given for stopping it by women who had established successful lactation was that they had too little milk to satisfy an infant whose demands were increasing with his size.

In a recent survey carried out for the Birds Eye Annual Review (1978), on 'food myths', it emerged that $85 \%$ dismissed the idea that pregnant and lactating women needed to 'eat for two'. The publicity 'blurb' that went out with this publication was widely quoted, both in the press and on radio, and the fact that this 'myth' was dismissed by $85 \%$ of mothers was highlighted as one of the most encouraging findings of the survey. Encouraging from the point of view of slimming maybe, but what about lactation? For poor people in the developing countries the issue is more acute; adequate provision of breast milk is of life and death importance for the majority of infants. Yet it is known that many nursing mothers are receiving less than $50 \%$ of the recommended allowances for energy and most nutrients. It is arguable that protein-energy malnutrition in the young pre-school child in fact begins with the under-feeding of the mother.

It is unfortunate, however, that so few quanti- tative studies, either in the under-developed or the industrialized countries, have been carried out where breast-milk output and quality have been directly compared with maternal dietary intake; the evidence that links diet to milk output is largely circumstantial. In the United Kingdom, Thomson, Hytten and Billewicz (1970) in Scotland, Naismith and Ritchie (1975) in London, and Whichelow (1976) in Cambridge have all shown that successfully lactating women have much higher daily energy intakes than bottle-feeding mothers (Table 3). But this does not

TABLE 3. Energy intakes (kcal/day) of mothers with breastfed or bottle-fed infants

\begin{tabular}{lll}
\hline & $\begin{array}{c}\text { Breast-fed } \\
\text { mean }( \pm \text { s.e. mean) }\end{array}$ \\
\hline Thomson et al. (1970) & $2716(107)$ & $2125(76)$ \\
Naismith and Ritchie (1975) & $2930(106)$ & $2070(127)$ \\
Whichelow (1976) & 2728 & 1958 \\
\hline
\end{tabular}

prove that dietary insufficiency is linked with the need to bottle feed. In the developing countries tutal energy intakes of $1500-1800 \mathrm{kcal} /$ day and $20-50 \mathrm{~g}$ protein are commonplace. In all studies so far published, but unfortunately in different sets of women, mean breast-milk output is considerably lower than the $850 \mathrm{ml} /$ day which forms the basis of most expert committee reasoning and the $720-760 \mathrm{ml} /$ day which was the average output found in a recent study of Swedish women (Lönnerdal, Forsum and Hambraeus, 1976).

In The Gambia, as shown in Fig. 1 (Whitehead et al., 1978), there is a marked seasonal variation in the food energy intake of lactating women. During the rainy season the energy expenditure of women is also greatly increased because of the high level of farming activities at this time. It is strongly suggestive from the present data that these 2 factors - heavy manual work and reduced maternal food intake - are associated not only with dramatic alterations in body weight but also with a reduced milk output. It has also been demonstrated that this reduced milk output is not primarily because of less frequent feeding, but because the amount of milk produced per feed is reduced. The author's provisional conclusion is that the actual capacity for milk production by the women is reduced. Simple regression analysis between food intake and milk output, however, does not produce a particularly high correlation. Presumably, if we had had an accurate way of measuring the routine energy expenditure of the women, the balance between energy intake and energy output would produce better correlations.

Only a few direct attempts have been made in the developing countries to see whether or not maternal dietary supplementation can actually increase milk 


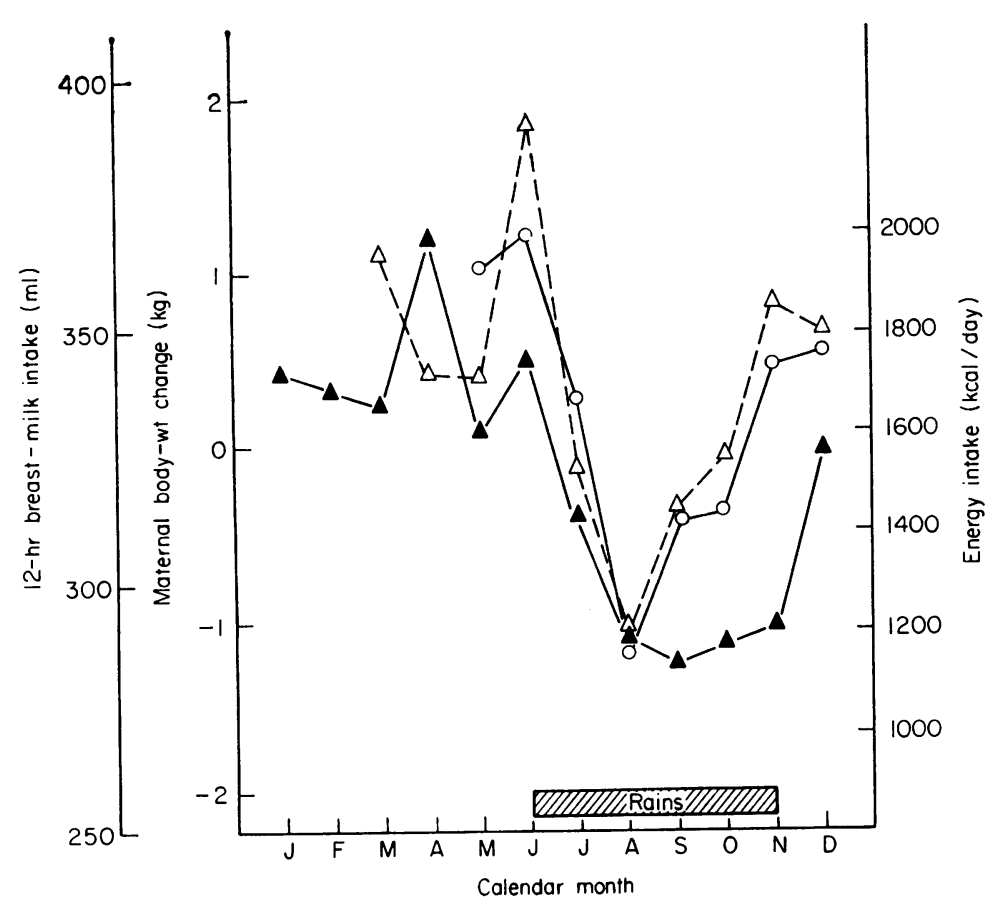

FIG. 1. Seasonal variations in food energy intake, body weight and milk output in rural Gambian women (Whitehead et al., 1978). $\triangle-\cdots \Delta$ Energy intake; $0 \longrightarrow 0$ maternal body weight; $\Delta \longrightarrow \Delta$ milk output.

yield. In general it is fair to say the results from these studies have not been particularly inspiring. The amount of extra milk produced has not been striking; although some improvement was usually evident, a poor lactator was rarely transformed into a good one. Outputs were still well below $850 \mathrm{ml} /$ day. It must be pointed out, however, that the nature of the dietary supplementation has not always been particularly rational.

Two early reports, by Adair (1925) and Kleiner, Tritsch and Graves (1928), recorded only slightly increased volume in earlier lactation as a result of supplementation, but the supplements were largely carbohydrate in nature. Deem (1931) investigated the effect of supplementation using a variety of diets, but just for a short time. Only a $10 \%$ increase in milk output was achieved, although this could have been due to the short investigative period. In the Wuppertal study, carried out after World War II, Gunther and Stanier (1951) actually observed lower breast milk outputs in groups supplemented with fat or with protein and carbohydrate. Here there seem to have been sample selection problems.

In the Belgian Congo, Holemans, Lambrechts and Martin (1954) investigated the milk yield of 27 women who had been receiving $40 \mathrm{~g}$ of skimmed milk/day for one year. This provided a useful protein supplement but not much dietary energy to support its metabolism. The results are shown in Fig. 2. Although there was some improvement, the total volumes were still low; the beneficial effect was really only significant in early infancy.

Gopalan (1958) also studied the effect of protein supplementation by maintaining 6 women with 5 - to 13-month-old infants on diets containing 61, 99 and $114 \mathrm{~g}$ of protein respectively for consecutive periods of 10 days. The total energy content of these diets was $2900 \mathrm{kcal}$. The test-weighed mean milk outputs, however, for each period were only 402, 512 and $490 \mathrm{ml} /$ day respectively. But the investigative period of that study was rather short to be of significance.

One of the best studies carried out is that of Chavez, Martinez and Bourges (1975) in Mexico. This was a 2-year longitudinal study in a poor and inadequately nourished rural community. The diet of the mother was supplemented from the 45th day of gestation until weaning, with an extra $300 \mathrm{kcal} /$ day. During the first 6 months of lactation the mean volume of milk secreted was $15 \%$ higher than in non-supplemented mothers, but it was also found that the milk of the supplemented mothers was more dilute (Fig. 3) and thus the nutrient benefit to the 


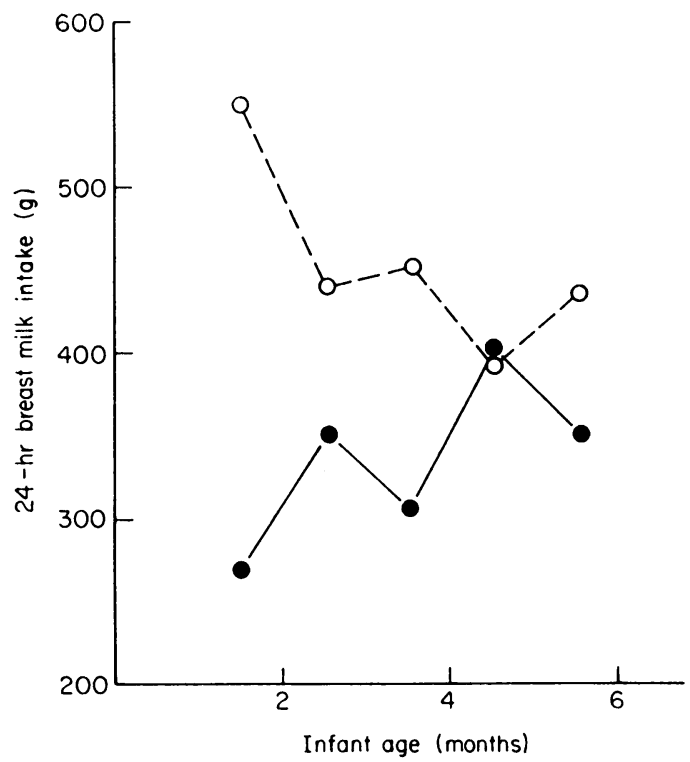

FIG. 2. The effect of maternal dietary supplementation with skimmed milk on breast milk output in Congolese women (Holemans et al., 1954). O--.-O Supplemented mothers; $\longrightarrow$ non-supplemented mothers.

child was only minimal. The problem with this study could have been that $300 \mathrm{kcal}$ was insufficient to boost baseline intakes to a satisfactory level. No data were provided on the home intakes of the mothers. There is another possible explanation: preliminary

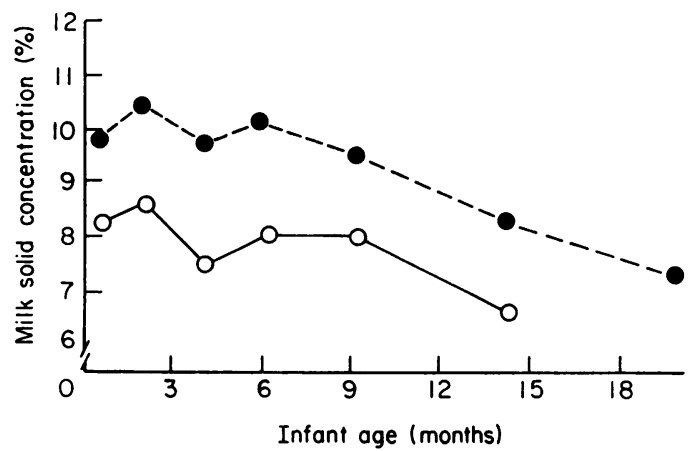

FIG. 3. Effect of maternal dietary supplementation on the solid content of breast-milk of Mexican women (Chavez et al., 1975). O----O Supplemented mothers; - - - - non-supplemented mothers.

data from The Gambia has revealed additional interrelationships (Paul, Müller and Whitehead, 1979). Figure 4 shows the association between changes in the subcutaneous fat of nursing mothers during the second 6 weeks of lactation, and their dietary intake. Average customary energy intakes were considerably below the recommended value, but in spite of this many of the lactating women are actually laying down fat, and the higher their energy intake, the more subcutaneous fat they are storing. It is conventionally assumed that subcutaneous fat is lost during lactation, not gained. Thus, in the undernourished mother there could be competition between the replenishment of maternal subcutaneous

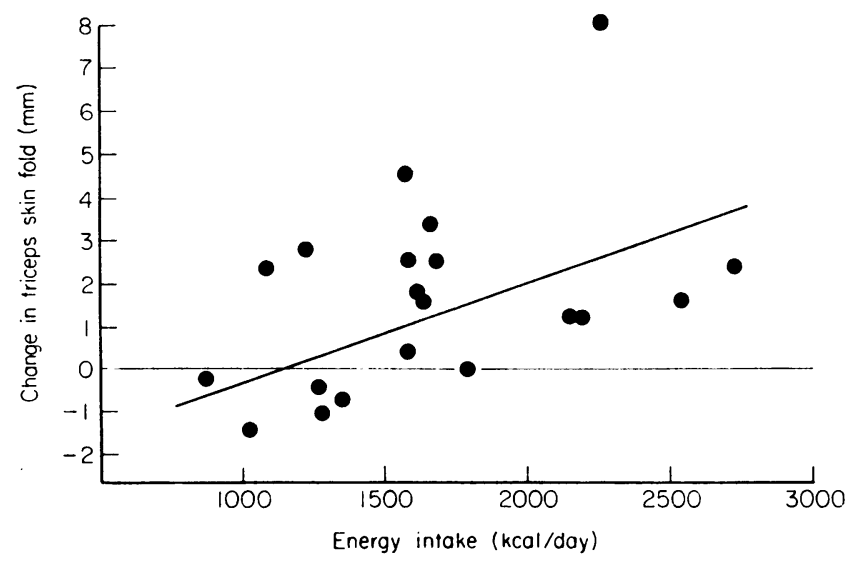

Fig. 4. Relationship between different dietary energy intakes and the triceps skin fold thickness of Gambian women (Paul, Müller and Whitehead, 1979). $r=0.4414 ; n=20 ; P<0.05$. 
fat stores and the production of milk. In such circumstances it would not be surprising if any improved yield of milk arising after dietary supplementation were less than expected.

This last finding emphasizes that for successful lactation it is probably insufficient to supplement just during lactation. More likely, what is required is a general improvement in the nutritional status of women.

\section{Diet and the nutritional quality of human milk}

Let us consider maternal diet and milk quality. Is the latter, as many believe, sacrosanct? The quick answer would appear to be no. In general, the total energy content of breast milk does tend to be lower in the undernourished mother. Figure 5 shows provisional data covering the first year of lactation in The Gambia. The data were obtained from milk samples collected at 2 different times: one, at the beginning of the rains, and one, after a period of low energy intake and high energy expenditure at the end of the rains. The energy content was lower in the latter samples.

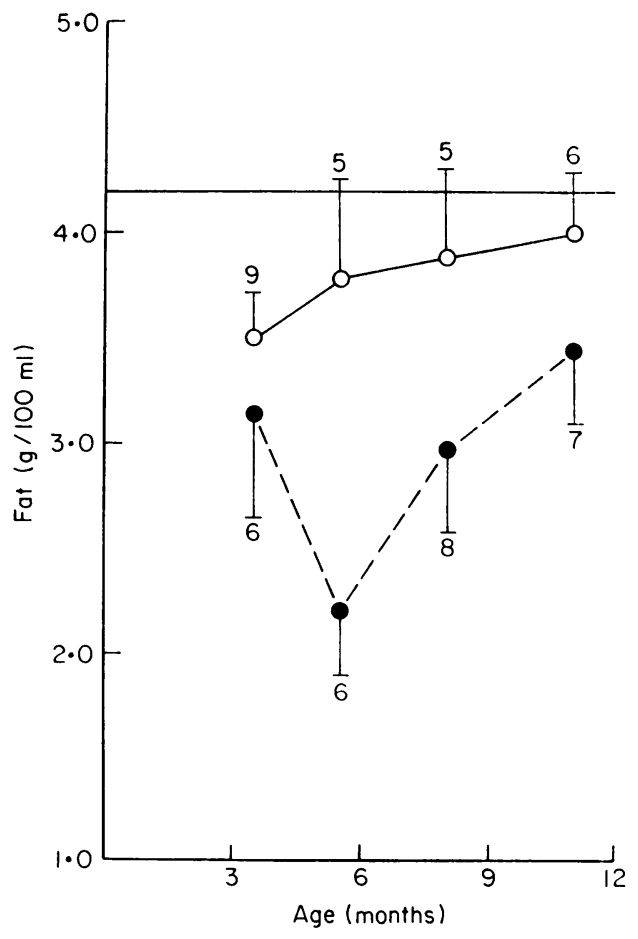

FIG. 6. Fat content of Gambian human milk. (U.K. data from DHSS, 1977). O-O Start of rains; --.-๑ end of rains; - U.K. milk.

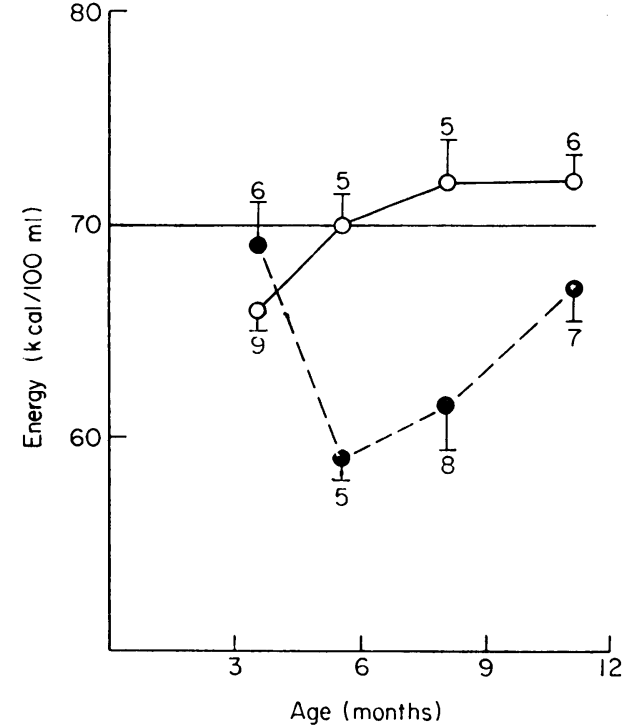

FIG. 5. Energy content of human milk at 2 different times of the year from Gambian women. (U.K. data from DHSS, 1977). O- O Start of rains; ----@ end of rains; - U.K. milk.

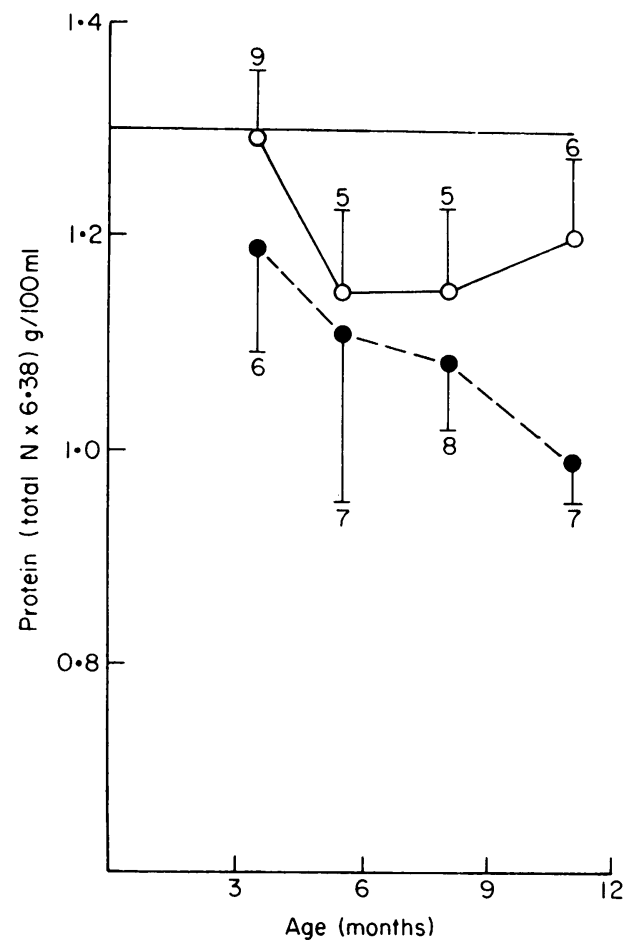

FIG. 7. Protein content of Gambian human milk. (U.K. data, from DHSS, 1977). O— 0 Start of rains; end of rains; $\_$U.K. milk. 
The mean fat content in the milk of well nourished subjects is around $4.2 \mathrm{~g} / 100 \mathrm{ml}$ (DHSS, 1977); but reports of the fat content in human milk from a number of developing countries have provided values considerably lower than this (Belavady and Gopalan, 1959; Crawford, Laurence and Munhambo, 1977), values from New Guinea being particularly bad around $2.5 \mathrm{~g} / 100 \mathrm{ml}$ (Bailey, 1965; Venkatachalam, 1962). The author's own provisional data from Gambian mothers are shown in Fig. 6. After the stress of intensive agricultural work and generally poor energy intakes during the rains, the fat content was especially low. This is the main reason for the low energy content. The average carbohydrate content in the milk of British women is $7 \cdot 4 \mathrm{~g} / 100 \mathrm{ml}$ (DHSS, 1977) and most studies from undernourished communities have failed to demonstrate any significant difference between the lactose content of well nourished and under-nourished subjects. In The
Gambia the lactose concentration tends to be higher at the end of the rains, but only marginally so.

In the case of protein, the average concentration in the milk of well nourished mothers is around $1.2 \mathrm{~g} / 100 \mathrm{ml}$. Malnutrition does not seem to affect this value greatly, although the author's own preliminary data (Fig. 7) again suggest seasonal differences.

The vitamin content of milk also seems to be dependent on the nutritional status of the mother and Fig. 8 shows this relationship for nicotinic acid, ascorbic acid, thiamine, and riboflavine. These data come from a study of Deodhar and Ramakrishnan (1960) in Baroda, India, but similar findings have also been reported by other workers.

It can be said in conclusion that although there is strong circumstantial evidence to suggest that the capacity of the mother to produce sufficient amounts of breast milk of high nutritional quality is influenced
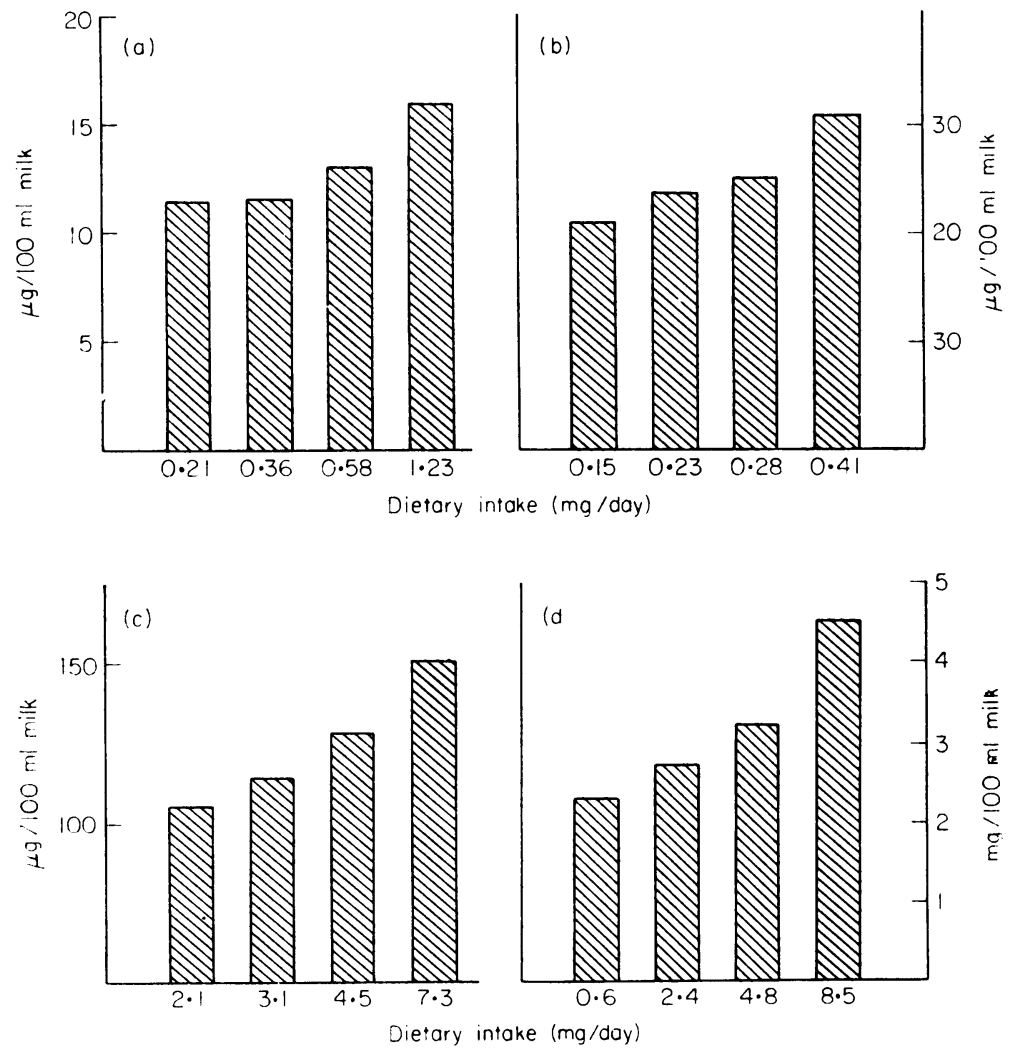

FIG. 8. Vitamin contents of milk from Indian women at different levels of intake (Deodhar and Ramakrishnan, 1960). (a) Thiamine, (b) riboflavine, (c) nicotinic acid. (d) vitamin $\mathrm{C}$. 
by her dietary status, more practically orientated work needs to be done before we can make unreserved recommendations at the public health planning level. In the meantime, those directly responsible for the health and welfare of nursing mothers and their babies should be taking due note of the possibility that maternal nutritional status could be an important factor influencing not only the outcome of pregnancy but also the ability of the mother for long-term successful lactation.

\section{References}

ADAIR, F.L. (1925) Influence of diet on lactation. American Journal of Obstetrics and Gynecology, 9, 1.

BAILEY, K.V. (1965) Quantity and composition of breastmilk in some New Guinean populations. Journal of Tropical Pediatrics, 11, 35.

Belavady, B. \& Gopalan, C. (1959) Chemical composition of human milk in poor Indian women. Indian Journal of Medical Research, 47, 234.

Birds Eye ANNUAL Review (1978) What Every Housewife Knows. Birds Eye Foods Ltd, Walton-on-Thames.

Chavez, A., Martinez, C. \& Bourges, H. (1975) Role of lactation in the nutrition of low socio-economic groups. Ecology of Food and Nutrition, 4, 159.

Crawford, M.A., Laurence, B.M. \& Munhambo, A.E. (1977) Breast feeding and human milk composition. Lancet, i, 99.

DEEM, H.E. (1931) Observations on the milk of New Zealand women. I. The diurnal variation in the fat content of human milk. Archives of Disease in Childhood, 6, 53.

Deodhar, A.D. \& Ramakrishnan, C.V. (1960) Studies on human lactation. Relation between the dietary intake of lactating women and the chemical composition of milk with regard to vitamin content. Journal of Tropical Pediatrics and Environmental Child Health, 6, 44.

Department of Health AND Social Security (1969) Recommended Intakes of Nutrients for the United Kingdom. Report on Public Health and Medical Subjects, No. 120. H.M. Stationery Office, London.

Department of Health and Social Security (1977) The Composition of Mature Human Milk. Report on Health and Social Subjects, No. 12. H.M. Stationery Office, London.

FAO/WHO (1962) Report of a FAO/WHO Expert Committee on Calcium Requirements. WHO Technical Report Series, 230, FAO, Rome.

Gopalan, C. (1958) Studies on lactation in poor Indian communities. Journal of Tropical Pediatrics, 4, 87.
Gunther, M. \& Stanier, J.E. (1951) The volume and composition of human milk. In: Studies of Undernutrition, Wuppertal 1946-49. Medical Research Council Special Report Series No. 275, p. 379. H.M. Stationery Office, London.

Holemans, K., Lambrechts, A. \& Martin, H. (1954) Etude qualitative et quantitative du lait des femmes indigènes du Kwango (Congo belge). Revue médicale de Liège, 9, 714.

HytTEN, F.E. (1979) Nutrition in pregnancy. Postgraduate Medical Journal, 55, 295.

Kleiner, I.S., Tritsch, J.E. \& Graves, L.G. (1928) Influence of supplementary feeding of carbohydrates upon lactation. American Journal of Obstetrics and Gynecology, 15, 172.

LönNerdal, B., Forsum, E. \& Hambraeus, L. (1976) A longitudinal study of the protein, nitrogen and lactose contents of human milk from Swedish well nourished mothers. American Journal of Clinical Nutrition, 29, 1127.

MARTIN, J. (1978) Infant Feeding 1975: Attitudes and Practice in England and Wales. Office of Population Censuses and Surveys, Social Survey Division. H.M. Stationery Office, London.

National Research Council (1974) Recommended Dietary Allowances, 8th edition. National Academy of Sciences, Washington D.C.

NAISMITH, D.J. \& Ritchie, C.D. (1975) The effect of breastfeeding and artificial feeding on body-weights, skinfold measurements and food intakes of forty-two primiparous women. Proceedings of the Nutrition Society, 34, 116A.

Paul, A., Müller, E. \& Whrtehead, R.G. (1979) Seasonal variations in energy intake, body-weight and skin-fold thickness in pregnant and lactating women in rural Gambia. Proceedings of the Nutrition Society (in press).

RAPHAEL, D. (1976) The Tender Gift: Breastfeeding. Schocken Books, New York.

Thomson, A.M., Hytten, F.E. \& Billewicz, W.Z. (1970) The energy cost of human lactation. British Journal of Nutrition, 24, 565.

Venkatachalam, P.S. (1962) A study of the diet, nutrition and health of the people of the Chimbu area. Territory of Papua and New Guinea, Department of Public Health Monograph No. 4.

WhICHELOW, M.J. (1976) Success and failure of breast feeding in relation to energy intake. Proceedings of the Nutrition Society, 35, 62A.

Whitehead, R.G., Rowland, M.G.M., Hutton, M., Prentice, A.M., Müller, E. \& PaUl, A.A. (1978) Factors influencing lactation performance in rural Gambian mothers. Lancet, ii, 178. 